\title{
Perspektif Hukum Dalam Ruang Publik Masyarakat Demokrasi
}

\author{
Radita Gora \\ Universitas Satya Negara Indonesia \\ Email: radita.gora026@gmail.com \\ Received : 17 Mar 2021 | Revised : 25 Apr 2021 | Accepted : 2 May 2021 | Published : 10 Jun 2021

\begin{abstract}
Law in society focuses on the problem of authority and control that allows the collective life of humans to always be in a relatively orderly and orderly state. The power of government control and authority as the bearer of state power that underlies control is what is formed in a system of rules called "Law", or also called the term "National Laws." The law creates a mechanism that translates communicative power into administrative powers mandated by the holders of the trias politica. The existence of law is certainly also not free from the existence of public space that is shaded by the scope of communication in the form of opinions or ideas of the community in realizing its order. The public space basically requires a free society in the context of democracy and politics, on the one hand the law essentially protects the freedom of members of society. So that the legal link in the public space is re-referring to three basic legal values, namely Equality, Freedom, and Solidarity.
\end{abstract}

Keywords: Law, Public Sphere, Power, Democracy

\begin{abstract}
ABSTRAK
Hukum dalam masyarakat berfokus pada masalah otoritas dan kontrol yang memungkinkan kehidupan kolektif manusia selalu berada dalam keadaan yang relatif tertib dan berketeraturan. Kekuatan kontrol dan otoritas pemerintah sebagai pengemban kekuasaan negara yang mendasari kontrol itulah yang terbentuk dalam suatu sistem aturan yang disebut dengan "Hukum", atau disebut juga dengan istilah "Hukum Perundang-undangan nasional". Hukum menciptakan sebuah mekanisme yang menerjemahkan kekuasaan komunikatif ke dalam kekuasaan administratif yang diamanahkan oleh pemegang trias politica. Keberadaan hukum tentunya juga tidak lepas dari adanya ruang publik yang dinaungi lingkup komunikasi berupa pendapat atau gagasan masyarakat dalam mewujudkan keteraturannya. Ruang publik pada dasarnya menghendaki masyarakat yang bebas di dalam wadah demokrasi dan politiknya, di satu sisi hukum secara hakiki melindungi kebebasan para anggota masyarakat. Sehingga kaitan hukum di dalam ruang publik adalah kembali mengacu pada tiga nilai dasar hukum, yaitu Kesamaan, Kebebasan, dan Solidaritas.
\end{abstract}

Kata Kunci: Hukum, Ruang Publik, Kekuasaan, Demokrasi 


\section{PENDAHULUAN}

Masyarakat sebagai sebuah institusi dari kumpulan individu yang bersifat fluktatif dan memiliki dinamika yang tentatif, menjadikan sebuah ciptaan keragaman masyarakat yang terkumpul dalan suatu dinamika kehidupan yang bervariasi dengan kalkulasi permasalahan sosial yang tidak statis setiap hari, bahkan setiap tahunnya. Adapun warga masyarakat juga menjadi suatu komunitas kelompok masyarakat lokal yang otonom dengan tradisi yang telah diterima dan dipatuhi masyarakat dalam kualitasnya sebagai asas-asas moral akan hidup di dalam sembari warga masyarakat yang sebagai bagian dari the living law.

Bersubstansi moral, hukum yang hidup di dalam asnubari rakyat ini tak kunjung putus akan selalu diakui oleh anggota masyarakat sebagai segugus pedoman normatif yang akan menuntun perilaku yang dipandang amat patut di dalam masyarakat. Asas-asas moral mencerminkan kearifan moyang masyarakat setempat yang berada pada ranah moral ini, dan umumnya terumus amat umum, dan terbuka untuk sembarang tafsir oleh siapapun ketika menghakimi suatu perkara yang kongkrit. Di sini, namun begitu, kongkretisasinya yang akan dpaat didayagunakan untuk mengontrol perilaku manusia dalam bermasyarakatnya, masih akan ditentukan dari kasus ke kasus.

Menarik ke belakang tentang sejarah perkembangan hukum di dalam masyarakat, mengutip dari pandangan Hobbes dalam Magnis (Hardiman, 2010) mengatakan bahwa semula manusia hidup tanpa negara, semata-mata menurut "hukum alam". Tak ada orang yang berwenang untuk memerintah atas orang lain. Di antara hak-hak alam juga termasuk hak untuk membela diri terhadap segala serangan atas hak-hak asasi tadi serta untuk menghukum penyerang itu. Akan tetapi, lamakelamaan situasi tanpa aturan tidak tertahan lagi. Ancaman terhadap keamanan bertambah dan ancaman itu tidak bisa diatasi oleh masing-masing pihak yang terancam. Karena itu individu-individu bersepakatan untuk mendirikan sebuah lembaga yang bertugas untuk melindungi hak-hak asasi mereka. Lembaga itu Commonwealth (bukan merk dagang). Commonwealth itu mempunyai tiga tugas: menetapkan aturan yang berlaku bagi semua (legislative power), melaksanakan aturan-aturan itu (executive power) dan mengatur hubungan dengan Commonwealthcommonwealth lain (federative power).

Kekuasaan negara itu, pertama, dibatasi oleh parlemen karena legislatif ditentukan oleh para warga dan undang-undang harus dibuat bersama oleh parlemen yang hasil pemilihan itu dan raja. Dan kedua, kekuasaan negara terbatas karena harus menjamin hak-hak asasi (the inalienable rights) para warga. Masyarakat warga didominasi oleh lembaga-lembaga pasar dan organisasi-organisasi kelasnya yang terkait. Negara bukanlah pemenuhan rasionalitas universal namun sekedar merupakan agen kelas dominan yang pemenuhan kepentingannya dipertahankan melalui kekerasan yang terorganisir oleh negara. Dalam pandangan Marx, kita tidak melihat masyarakat warga sebagai entitas yang memiliki hubungan oposisi dengan negara. Sebaliknya, masyarakat warga tergantung pada negara.

Dalam masyarakat warga atau masyarakat politis itu John Locke menyebut beberapa unsur fundamental demokrasi modern, atau kalau mau, etika politik modern, terwujud dalam Suseno (Hardiman, 2010). Prinsip kedaulatan rakyat: segala wewenang atas masyarakat harus datang dari masyarakat itu, kemudian prinsip negara minimal dalan arti bahwa wewenang negara dibatasi oleh rakyat yang berdaulat pada apa yang perlu agar negara dapat melakukan tujuan untuknya ia didirikanL melindungi 
masyarakat. Pembagian kekuasaan, yang dimana pada pembagian Locke yang masih kurang sempurna ke dalam kekuasaan legislatif, eksekutif dan federative akan dilengkapi, menjadi trias politik, oleh Charles de Secondar Montesquieu (1689-1755), seorang pengagum Locke dan tokoh Liberalisme Perancis, dengan menambah kekuasaan yudikatif, artinya kehakiman (sedangkan kekuasaan federative dimasukkan ke dalam kekuasaan eksekutif). Prinsip pembagian kekuasaan adalah mendasar bagi negara modern di dalamnya berakar paham negara hukum.

Prinsip bahwa kekuasaan negara adalah terbatas. Pembatasan ini dirumuskan dalam Undang-Undang Dasar yang menetapkan secara rinci wewenang tiga kekuasaan negara itu. Artinya bahwa negara menjalankan seluruh kekuasaannya atas dasar sebuah Undang-Undang Dasar. Keterbatasan itu juga kelihatan dalam penegasan Locke bahwa rakyat boleh melawan, bahkan boleh melakukan revolusi apabila negara melanggar hak-hak asasinya.

Unsur-unsur ini tak kurang menjadi tonggak-tonggak martabat kenegaraan modern: Negara hukum yang berdasarkan sebuah Undang-Undang Dasar, jaminan terhadap hak-hak asasi, pembatasan kekuasaan negara, kedaulatan rakyat, legislatif yang dibentuk sebagai lembaga perwakilan rakyat. Hasil-hasil liberalisme politik ini sekarang masuk ke dalam paham demokrasi yang normatif bagi kenegaraan yang etis dan beradab.

Pada dewasa ini, masyarakat tidak lagi dipandang sebagai objek pasif pemerintahan dari atas, melainkan bersama dengan sistem susunan kuasa-kuasa negara merupakan sebuah komunitas atau sistem interaktif. Sehingga dari sini dapat diartikan bahwa masyarakat warga adalah keseluruhan masyarakat karena, apabila negara disusun menurut Locke, masyarakat iu berinteraksi aktif dengan negara. Sehingga isi suatu negara kemudian menjadi bagian dari ruang public dari masyarakat. Negara sebagai wadah bagi masyarakat yang di masyarakat membentuk suatu koloni bagi dirinya sendiri.

Pada permulaan, dalam keadaan alami, tidak demikian keadaan manusia. Setiap orang masih hidup sendiri-sendiri, tanpa ikatan sosial, mengejar kepentingannya sendiri, tetapu dengan sikap baik dan positif terhadap sesama. Akan tetapi lama kelamaan manusia menjadi lebih kaya, maka ia mulai saling mengiri dan curiga. Maka kehidupan bersama mulai diatur dan terjadi apa yang disebut masyarakat. Masyarakat itulah sumber segala kebusukan. Suseno dalam (Hardiman, 2010)

Tetapi ada cara untuk mewujudkan masyarakat di mana semua betul-betul bebas. Masyarakat itu sipil karena para warga akan meerupakan citizen yang aktif menangani negara. Masyarakat sipil itu diciptakan dalam sebuah kontrak sosial baru. Masyarakat itu bebas karena hidup di bawah sebuah hukum yang ditetapkan oleh rakyat sendiri. Hukum itu diberikan secara sewenang-wenang oleh raja, melainkan merupakan hukum ciptaan rakyat sendiri. Undang-undang dibuat oleh rakyat sendiri. Maka dalam menaati hukum rakyat menaati diri sendiri dan karena itu tetap bebas.

Rasionalisasi pemikiran tiba pada ajaran 'kontrak sosial', yang menyatakan bahwa setiap hukum yang berlaku dalam kehidupan berbangsa ini haruslah berupa hukum yang dihasilkan oleh hasil kesepakatan yang diperoleh lewat perjanjian antar warga atau melalui wakilnya, yang kemudian diundangkan sebagai undang-undang nasional yang akan ditegakkan sebagai standar perilaku warga bangsa yang sentral dan tunggal. Demikianlah rasionalisasi dalam penciptaan hukum nasional mengakhiri keyakinan bahwa hukum yang bekerja sebagai penertib kehidupan ini sesungguhnya merupakan bagian saja dari tertib semesta yang kodrati, yang tidak sekali-kali 
bersumber pada otoritas manusia yang mengenal kematian, melainkan dari kekuatan "Dia yang bertahta di langit sana". (Wignjosoebroto, 2013a)

Teori atau doktrin 'kontrak sosial ini menyiratkan dasar moral pembenar yang baru bahwa kekuasaan para pejabat negara itu berasal dari yang atas dasar kebebasannya membuat persetujuan untuk melepaskan diri dari kebebasan mereka yang alami yang mengikatkan diri ke dalam kehidupan bersama. Di sini kebebasan individual setiap warga negara untuk di satu pihak juga untuk menyepakatkan jaminan perlindungan atas kebebasan, dan di lain pihak juga untuk menyepakatkan batas kebebasan yang akan menjamin kesediaan warna untuk terikat pada hukum, itulah yang merupakan legitimasi berdirinya organisasi kehidupan manusia di bumi ini. Kebebasan dan keterikatan adalah dua sisi mata uang yang tak mungkin dipisahkan. (Wignjosoebroto, 2002)

Pandangan dari Locke ini kemudian menjadi bertentangan dengan pandangan dari Hegel yang mampu maju dalam pengertian masyarakat warga, Hegel tidak lagi memahaminya sebagai masyarakat dalam kesatuan dengan kenegaraannya, melainkan sebagai wilayah kehidupan masyarakat tersendiri. Tersendiri dalam arti, bahwa masyarakat warga adalah masyarakat justru sejauh tidak terkait dengan kenegaraan. Maka masyarakat warga dalam pengertian Hegel adalah segala kehidupan sosial, segala kegiatan yang di satu pihak tidak termasuk dalam kehidupan berkeluarga, dan di lain pihak tidak terkait dengan kekuasaan negara (legislatif, eksekutif, yudikatif).

Sementara itu baik Locke maupun Rousseau memahami seluruh masyarakat sebuah negara sebagai masyarakat warga, termasuk aparat pemerintahannya. Apabila rakyat melakukan segala macam kegiatan di bawah paying hukum dan kekuasaan eksekutif menurut sebuah Undang-undang dasar (Locke), atau, di mana rakyat patriotic sendiri mengurus kekuasaan negara dan dengan demikian merupakan kesatuan sosial yang menjalankan sendiri kehidupannya, yang bukannya berada di bawah hukum yang dipasan dari luar oleh seorang raja, itulah masyarakat warga. Bagi Hegel, masyarakat warga meliputi kehidupan dan kegiatan di luar rumah, jadi pekerjaan professional, berbelanja, memakai fasilitas umum, misalnya bisa untuk perjalanan, untuk rekreasi seperti nonton pertandingan olahraga Asian Games 2019, olah raga sendiri, menjadi wisatawan dan lain sebagainya, lalu juga kehidupan budaya dalam arti kesenian. Bahkan di dunia sekarang media termasuk masyarakat warga.

Hegel memandang bahwa pada institusi masyarakat warga dan hukum masyarakat pada dasarnya hidup dilingkaran individu itu sendiri karena dilihat pada aspek pergerakan, tindakan dan pemikiran seseorang untuk bertindak sehingga disini masyarakat memanfaatkan sarana untuk melakukan tindakan dan aksinya tersebut termasuk untuk hal-hal yang bersifat kriminil. Hegel memahami masyarakat warga sebagai lapisan kehidupan masyarakat tersendiri, terpisah dari, dan berhadapan dengan negara. Masyarakat warga adalah wilayah di mana kehidupan berlangsung kalau mereka tidak dirumah mereka sendiri, Masyarakat warga itu tidak politis. Orang mengejar kepentingan sendiri, tetapi merasa aman karena diwaspadai oleh negara yang sudah tercerahkan, artinya yang sistem hukum dan pemerintahan sudah republikan. Suseno dalam (Hardiman, 2010)

Masih menurut Hegel bahwa kalau hanya ada civil society sebagai "sistem kebutuhan", kekuatan-kekuatan sentrifugal akan menang dan masyarakat akan terpecah-belah. Maka perlu ada negara yang bermotivasi kepentingan umum. Melalui hukum negara memberikan kerangka bagi kebebasan para warga. Hukum adalah batas kebebasan para warga negara. 
Kajian-kajian tekstual terhadap hukum berkembang dengan sebutan jurisprudental sepanjang abad ke 18-19 di negeri-negeri kelahirannya. Kajian ini banyak berseluk beluk dengan upaya mensistematisasi berbagai produk perundangundangan berikuti prosedur-prosedur pendayagunaannya serta ajaran-ajaran yang menjadikan preskripsi-preskripsi undang-undang yang bertebaran itu terorganisasi ke dalam suatu sistem yang logis dengan koherensinya pada taragnya yang tinggi. Tetapi, sudah pada belahan kedua abad 19 yang bersiterus ke abad 20, tatkala industrialisasi dan urbanisasi telah serta merta menyebabkan terjadinya perubahan masyarakat yang sungguh eksponensial, dorongan utnuk juga mempelajari teks-teks itu ialah sehubungan dengan perubahan konteks-konteksnya dengan segera saja menguat.

Meningkatnya migrasi dan urbanisasi yang kian membikin komplek secara drastis heterogenittas dan pluralitas kehidupan, atau pula maraknya kekumuhan dan kemiskinan yang berseiring dengan terjadinya massa pekerja pabrik dan kejahatan yang merebak di kota-kota, adalah dua-tiga contoh saja dari sekian banyak perkembangan sosial-ekonomi yang menuntut terwujudnya sistem normatif baru guna menjamin terwujudnya tertib kehidupan yang baru pula. Sebelum datangnya masa krisis dengan segenap kerisauannya itu, para pemikir besar di bidang filsafat sosial amatlah berkeyakinan akan kebenaran paham progresisme. Ialah paham yang bertolak dari suatu paradigma saintisme yang empiris dan positif, bahwa perubahan macam apapun yang terjadi dalam sejarah kehidupan manusia, jejak langkahnya sudahlah pasti akan selalu berarah ke bentuk dan substansi yang secara kodrati akan lebih baik daripada yang sudah-sudah.

Hal ini kemudian dilihat bagaimana suatu ruang publik tidak selalu membenarkan atau kebenaran atas apa adanya, lantaran rasionalitas masyarakat dalam berpkir dan bertindakan di suatu ruang publik dan ruang privat juga menjadi hal yang dilematis dari aspek hukumnya. Sehingga dalam hal ini, perlu dilihat dalam suatu rumusan tentang persoalan tindakan-tindakan yang dinilai suatu bentuk gerakan yang demokratis, namun di satu sisi memanfaatkan ruang public sebagai gerakan demokratis yang bukan bertindakan suatu kepentingan masyarakat banyak, melainkan sebagai kepentingan masyarakat itu sendiri atau golongan tertentu. Sehingga muncul adanya kesenjangan-kesenjangan baru ( $\mathrm{gap}$ ) antar masyarakat di berbagai struktur dan terciptanya suatu kesenjangan dalam kasta-kasta masyarakat sosial dan budaya, strata atau kelas-kelas yang pada awal mulanya hanya hendak menggambarkan adanya perbedaan jenis kerja itu, kini karena adanya imbalan kehormatan yang melekat pada status anggota kelas yang diperbedakan secara ordinal (antara yang tinggi, tengah, dan rendah), lalu juga menjadi amat berpengaruh pada terjadinya pola perlakuan yang diskriminatif.

Perlakuan pola diskriminatif, yang kemudian berujung pada ketidaksepahaman dan mengganggu kewibawaan masyarakat, pada akhirnya memunculkan adanya konflik, baik itu perang dingin maupun peran fisik. Pelanggaran-pelanggaran ini kemudian melibatkan aspek hukum didalamnya dan upaya hukum untuk mengatasi ini kemudian bisa dikatakan bahwa hukum sudah mulai mengintervensi keberadaan ruang public.

Sehingga dari sini, permasalahan adanya kesenjangan ruang public dan konsep hukum yang dibangun oleh regulator serta bagaimana kontrol masyarakat didalamnya, serta konflik masyarakat yang mengutamakan kebebasan dan perlindungan dalam ruang privat. Mengikuti pandangan Hegel bahwa relasi-relasi sosial dalam masyarakat warga juga merupakan ekspresi dari konflik akibat relasi-relasi ekonomis. 
Berdasarkan rumusan ini, maka dapat disusun suatu pertanyaan:

1. Apa yang menjadi tonggak utama dalam konsep hukum dalam masyarakat dan ruang publik itu sendiri?

2. Bagaimana relevansi hukum dan ruang publik masyarakat demokrasi?

3. Mengapa keberadaan hukum dinilai penting dalam kehidupan masyarakat demokrasi didalam lingkup ruang publik?

\section{PEMBAHASAN}

Kehidupan masyarakat pra modern, tatkala kehidupan itu masih berada pada skalanya dan formatnnya yang lokal, homogeni dan eksklusif yang oleh sebab itu lebih cocok untuk diistilahi 'komunitas' (community) daripada 'masyarakat' (society) atau 'masyarakat negara' (political state), apa yang disebut 'hukum; ini umumnya tidak tertulis dan eksis sebagai asas-asas umum di dalam ingatan warga komunikasi, dirawat secara turun temurun sebagai tradisi yang dipercaya berasal dari nenek moyang. Inilah yang disebut tradisi atau moral kehidupan suatu komunitas, yang di dalam kajian sosilogi hukum sering juga disebut 'hukum rakyat', dan yang didalam ilmu hukum disebut 'hukum kebiasaan' atau 'hukum adat'.

Dalam perkembangan kehidupan yang lebih mutakhir, tatkala kehidupan bernegara bangsa menggantikan kehidupan-kehidupan lokal yang berskala kecil dan eksklusif, apa yang disebut hukum ini mulai menampakkan wajahnya yang tertulis. Inilah yang disebut hukum undang-undang, yang ditulis dalam rumusan-rumusan yang lebih eksak, dibentuk atau dibuat melalui prosedur tertentu, dan terstruktur atau terlembagakan sebagai sarana control yang nyata-nyata formal sifatnya, yang oleh sebab itu akan ditunjang oleh otoritas kekuasaan negara yang berkewarganegaraan untuk mendayagunakan sanksi. Karena sifatnya yang formal inilah maka hukum undang-undang yang diperlukan untuk mengontrol tertib kehidupan nasional ini, baik dalam hal prosedur pembuatannya maupun dalam hal prosedur pendayagunaannya, tak jarang disebut pula 'hukum formal'.

Dalam kehidupan bernegara yang disebut kehidupan negara bangsa apa yang disebut 'hukum' itu selalu atau hampir selalu saja diartikan sebagai seluruh adat atau normal sosial yang telah diformalkan oleh institusi-institusi kekuasaan negara. Hukum undang-undang ini (menurut doktrinnya yang disebut 'doktrin supremasi hukum') haruslah diterima sebagai pengganti mutlak berlakunya semua norma sosial macam apapun yang lain, yang ada di dalam masyarakat. Dalam statusnya seperti itu, hukum undang - undang akan berlaku sebagai hukum tertiunggi, mengatasi norma sosial macam apapun, juga yang dipercaya sebagai hukum "yang diwahyukan dari langit sebagaimana diajarkan oleh para Rasul dan Nabi”. (Wignjosoebroto, 2017)

Hukum yang berlaku di dalam undang-undang negara adalah berlakunya hukum nasional. Dikatakan demikian karena hukum macam ini diberlakukan sebagai standar untuk rujukan sentral seluruh perilaku warga bangsa, ialah penduduk yang sejak didirikannya organisasi kehidupan bernegara bangsa telah beroleh statusnya sebagai warga negara, Inilah hukum yang dibentuk secara sengaja dan rasional melalui suatu kesepakatan antara wakil-wakil rakyat dalam suatu badan perwakilan yang disebut 'badan legislatif'. Berseiring dengan perubahan dan perkembanan evolusioner organisasi-organisasi kehidupan itu, berkembang pula kesadaran baru yang mendasari perkembangan hukum yang bergerak dari hukum lokal ke nasional itu. Kesadaran baru 
apakah itu? ialah kesadaran baru yang humanistic tentang pentingnya manusia individu sebagai subjek pencipta hukum, hak dan sekaligus juga kewajiban.

Penciptaan hukum juga tidak lepas dalam historicalnya, dari pandanganpandangan kekuasaan sosial. Hal ini menuntut adanya suatu otonomi sosial dalam membangun struktur kekuasaannya agar dapat menciptakan aturan-aturan yang memaksa dengan mementingkan kepentingan serta kehendak bersama bukan atas golongan tertentu.

Menurut Heath, kekuasaan sosial meski memiliki kewenangan normatif, masih mengambil bentuk kehendak individu tertentu. Pekerjaan kuasa administratif, di lain pihak, dipisahkan dari kehendak atau kedaulatan individu dan dilekatkan pada aturan hukum. Sistem hukum menciptakan aturan dan kewenangan dasar yang menaungi usaha mencapai tujuan kolektif, dan memberi rakyat hak untuk boleh bertindak ketika ketentuan-ketentuan ini tidak berjalan. Akan tetapi, hukum bukanlah sekedar media untuk menerapkan kuasa administratif, namun juga memberikan legitimasi bagi pelaksana kuasa administratif tersebut. Di bawah aspek legislatifnya hukum mengklaim merepresentasikan kepekatan yang bisa diikuti dengan bebas oleh semua orang. Kalau pada awalnya ia lebih cenderung berbentuk konsensus keyakinan agama dengan latar belakang yang tidak bisa dipertanyakan, maka di era modern mengejewantahkan diri dalam doktrin kedaulatan rakyat yang menjadi dasar lembagalembaga demokratis.(Habermas, 2016).

Dengan melonggarkan persyaratan kewenangan normatif untuk membiarkan berkembangnya "hukum positif" dalam kerangka proses legislasi yang legitimet dan lebih luas, maka corak hukum modern memungkinkan berkembangnya pola organisasi seperti halnya dalam keorganisasian wartawan dan regulasi sosial yang jauh lebih kompleks. Karenanya ia menampilkan sebuah kemajuan evolusioner melampaui corak kuasa politik-legal yang seragam.

Perkembangan hukum yang diperlukan untuk mengontrol kehidupan Negara bangsa yang modern ini mencita-citakan terwujudnya jaminan akan kepastian dalam hal pelaksanaan hokum sebagai sarana piñata tertib itu. Hukum menurut modelnya yang baru ini diperlukan para reformis untuk mengatasi kesemena-menaan para penguasa otokrat di masa lalu dalam ihwal penciptaan dan pelaksanaan hukum. Sejak awal mula, para penguasa otokrat ini mengklaim dirinya secara sepihak sebagai penegak hokum yang bersumber dari kekuasaan Ilahi yang Maha Sempurna. Tiadanya rujukan normatif yang dapat didayagunakan untuk men check menjadikan hukum raja ini terkesan amat semena-mena dan represif. Tiadanya rujukan normatif juga menyebabkan tiadanya kepastian mengenai apa yang harus digolongkan sebagai rujukan normative yang berlaku guna menjamin keteraturan dalam kehidupan nasional, dan mana pula yang tidak atau belum. (Wignjosoebroto, 2013a)

Disinilah awal pemikiran yang hendak mengetahkan dan memperjuangkan ide bahwa apa yang dimaklumatkan sebagai hukum haruslah mempunyai statusnya yang positif, dalam arti telah "disahkan" tegas-tegas (positif) sebagai hukum, dengan membentuknya dalam wujud produk perundang-undangan. Inilah pemikiran positivism yang amat marak pada masa pasca revolusi Perancis, yang serta merta menolak segala bentuk pemikiran metafisik, dan menolak pula praktik-praktik penyelenggaraan tertib kehidupan atas dasar rujukan yang metayuridis.

Masih menurut Soetandyo (Wignjosoebroto, 2013b)bahwa setiap undangundang berikut unsur-unsur yang ada di dalamnya (yang disebut pasal atau ayat), ditandai secara resmi dengan penomoran. Setiap unsur ini terbaca sebagai aturan, 
berupa kalimat yang menyatakan ada tidaknya suatu peristiwa atau perbuatan tertentu (disebut fakta hukum, index facti), yang disusul dengan pernyataan tentang apa yang akan menjadi akibatnya (akibat hukum), Setiap kalimat pernyataan yang berfungsi sebagai aturan bersanksi ini memang acapkali dipersepsi dan dikonsepsi sebagai perintah-perintah untuk berbuat atau tak berbuat dengan segala konsekuensinya. Terbaca seperti itu, kalimat-kalimat tersebut tak salah kalau dipahami sebagai normanorma; namun demikian, didasar oleh paham positivisme yang bernalar atas dasar hubungan sebab-akibat, setiap kalimat yang terumus itu dapat pula dipersepsi dan dikonsepsi sebagai nomos. Maka, dalam khazanah peristilahan hukum nasional modern, setiap baris aturan dalam setiap undang-undang disebut 'norma-norma positif', dan keseluruhannya disebut 'hukum positif' (sebagai kata ganti istilah 'hukum perundang-undangan').

\section{A. Hukum Pada Ruang Lingkup Nasional dan Fungsinya sebagai Kontrol Sentral.}

Konteks historis negara hukum muncul karena pengalaman sejarah pahit dari perang-perang, kemelaratan sosiologis akibat mutlaknya kekuasaan raja. Namun lebih menyadarkan lagi adalah kenyataan pengalaman bahwa sumber kesewenangan yang mengeping-ngepingkan serta membuat rakyat jadi korban dan tumbal, biang keladinya adlaah tidak dikontrolnya kekuasaan itu. Karena itu paradigma yang lalu dipilih dan dikembangkan dengan sadar ada dua, Pertama, dibentuk struktur mekanisme pembagian kekuasaan (sebagai reaksi atas absolutisme kuasa) dalam 3 mekanisme, yaitu legislatif, eksekutif, dan yudikatif di mana syarat independensi satu sama lain mutlak untuk bisa saling mengontrol. Kedua, dibuat kontrol atau pengendali terhadap pelaksanaan kekuasaan dengan cara pengawasan lewat kesepakatan aturan main hidup bersama, yaitu "rule of law" atau tegaknya hukum. Dengan kata lain kredibilitas diletakkan pada kepastian penegakan hukum untuk menyelesaikan konflik kepentingan.

Hukum sebagai sarana kontrol sentral tidak lagi berfungsi sebagai upaya untuk mendamaikan dan menyerasikan kembali hubungan antar-warga dari sengketa ke sengketa. Belajar dari cara para yuris dari masa imperium Romawi, dalam (Wignjosoebroto, 2013a), bahwa hukum nasional pun telah dikonstruksi in abstracto sebagai undang-undang dan juga dibukukan bersamaan dengan surutnya otoritas Gereja dengan hukum kanoniknya, dan pula runtuhnya kekuasaan imperium Romawi yang telah terjadi lama sebelumnya, kekuasaan politik nasional mencari dasar otoritas hukum yang baru dengan sifatnya yang reformatif.

Transformasi terjadi berseiring dengan perubahan-perubahan sosial-politik, khususnya pada belahan akhir abad 18 dan pada dasawarsa pertama abad 19 . Kehidupan bernegara bangsa yang modern pada masa itu, yang terintegrasi ke dalam satuan-satuan territorial dengan penduduk yang mempunyai latarbelakang keyakinan moral-religius yang beragam-ragamm, amat memerlukan standar perilaku bersama yang baru dan segera. Diperlukanlah suatu sistem hukum baru, berikut kelengkapan institusi dan organisasi yang baru pula, yang diperlukan untuk menjaga kelangsungan struktur kehidupan yang sudah berformat dan berskala nasional.

Berbeda dengan karakteristik hukum dari masa lalu, yang juga direalisasi pada zaman Romawi, tertib hukum diupayakan dengan cara menetapkan sejak awal posisi setiap individu dalam status mereka masing-masing. Inilah status hukum yang disebut status aspkriptif, ialah status atau posisi yang telah ditetapkan oleh dan/atau menurut 
tradisi yang telah diikuti "secara membuta" dari generasi ke generasi. Ada status quo, ialah status yang telah ditetapkan "seperti itu" oleh tradisi yang dipertahankan terus oleh para penguasa yang lebih mapan, sejak awalnya. Dengan memahami status masing-masing yang askriptif itu, setiap individu akan mengetahui posisinya dan tak akan bertindak melampui posisi yang telah ditetapkan secara final demi hukum. Dengan demikian, kemungkinan untuk bersilang selisih akan tercegah, dan kehidupan yang selaras dan serasi pun dengan demikian secara serta merta akan terjamin.

Dalam konsepnya yang lebih kongkrit-faktual, seperti yang ditemui dalam kajian-kajian ilmu hukum yang mendasarkan diri pada paham pasca-rasionalisme yang disebut positivisme, 'kontrak sosial' adalah suatu proses perjanjian dan kesepatakan yang melahirkan apa yang disebut 'konstitusi'. Adapun yang disebut 'konstitusi' dalam konsepnya "yang modern" ini ialah tatanan yang menjadi bagaimana dasar suatu organisasi negara, yang berfungsi sebagai rujukan normatif, yang dengan demikian akan memberikan dasar pembenar, baik secara moral maupun secara legal, kepada segala aktivitas para pejabat pengemban kekuasaan negara. Suatu konstitusi yang dalam tradisi hukum tata negara-negara Eropa Kontinental lebih dikenali sebagai undang-undang dasar, yang oleh sebab itu selalu tertulis menetapkan batas-batas kewenangan setiap institusi dan mengatur hubungan kewenangan antara lembagalembaga negara. Tentang ihwal hubungan kewenangan antar lembaga ini kita diingatkan pada ajaran Trias Politica yang dikemukakan oleh de Montesquieu, yang nama lengkapnya adalah Charles-Louis de Secondat, baron de La Brede et de Montesquieu. (Wignjosoebroto, 2013a)

Melalui konstitusi itu, sesungguhya bukan cuma merupakan sehimpunan aturan formal yang tertulis belaka, melainkan suatu ide dan ideologi, maka setiap konstitusi harus dikaji tidak sebatas membaca apa yang dituliskan di situ. Setoap konstitusi harus dikaji dengan kemahiran membaca ide hukum yang terkandung di dalamnya, ialah rasional atau dasa pembenar yang mendasari kebenaran konstitusi.

Adapun pada dasarnnya 'kontrak sosial' adalah suatu fiksi, hasil teoretisasi di alam pemikiran, bahwa terbentuknya organisasi kehidupan bernegara, berikut lembaga-lembaga pemerintahannya, berasal dari kesediaan rakyat yang rasional untuk melepaskan sebagian dari hak-hak kebebasan kodratinya yang asasi, demi terselenggaranya kehidupan bersama yang tertib. Teori kontrak sosial ini menyiratkan adanya dasar moral pembenar bahwa kekuasaan para pejabat negara itu berasal tak dari sumber manapun kecuali dari persetujuan rakyat. Keterikatan rakyat pada segala bentuk aturan yang ditegakkan para pejabat kekuasaan negara, dengan demikian, akan termaknakan sebagai keterikatan atas dasar kedaulatan dan persetujuan mereka sendiri. Di sini terbangunlah konsep tentang terbatasnya kebebasan kodrati rakyat oleh suatu kekuatan yang tak lain daripada kebebasan rakyat itu sendiri, ialah kebebasan mereka untuk berkontrak sosial, yang tak termaknakan sebagai kebebasan untuk mengurangi kebebasan sampai batas tertentu.

Batas-batas kewenangan yang dinyatakan secara normatif dalam dan oleh konstitusi itu sesungguhnya tak hanya dimaksudkann untuk menyeimbangkan besaran kekuasaan masing-masing lembaga terhadap sesamanya, akan tetapi juga untuk menegaskan batas-batas kewenangan lembaga-lembaga negara tersebut, khususnya di hadapan hak kebebasan warga negara yang asasi. Apabila lembaga-lembaga negara itu baik terhadap sesamanya maupun dihadapan warga negara pada asasnya terbatas, sedangkan hak-hak konstitusional warga negara (yang dinalar sebagai bagian dari hak kodrati) pada asasnya tidak terbatas. Pembatasan, apabila diperlukan hanya bisa dilakuka berdasarkan kesepakatan warga negara sendiri, lewat suatu proses yang mesti 
dilaksanakan dalam suasana yang bebas. Inilah asas ajaran atau paham ideologik yang disebut konstitusionalisme. Tanpa dilandasai ajaran konstitusionalisme ini, tak ayal lagi setiap undang-undang dasar itu hanyalah seberkas dokumen tertulis yang formal dan tanpa ruh. (Wignjosoebroto, 2017)

Hukum nasional yang diberlakukan untuk manusia sebangsa serta yang sekaligus sewarga negara ini telah menggeser paradigma hukum lebih lanjut, tidak hanya yang berproses dari yang semua berperspektif moralitas Aristotelian ke yang berorientasi standar perilaku yang kongkrit, sebagaimana yang dibentuk dalam lafallafal preskriptif yang tentu saja tertulis, tetapi juga terkonsepsi sebagai apa yang disebut les teritorialis. Apabila ius romanum dan ius cononici merupakan hukum yang berlaku untuk orang (ius personam), hukum nasional berlaku di suatu teritori untuk orang-orang yang berada di teritori itu.

Seluruh substansi, struktur dan kultur hukum inilah yang di dalam perbincangan teori dan praktek hukum disebut 'sistem hukum'. Tanpa mengabaikan betapa banyak dan beragamnya sistem hukum di dunia ini, di Indonesia dan di banyak negeri bekas daerah jelajahan dan jajahan bangsa-bangsa Eropa Barat, sistem hukum nasional yang dikenal pada dasarnya adalah sistem hukum yang bermodelkann hukum nasional bangsa-bangsa Eropa. Terdapat dua ragam sistem hukum nasional di Eropa ini, ialah apa yang disebut 'civil law system' dan apa yang disebut 'common law system'. Sistem tersebut pertama bertolak dari tradisi yang semula dikembangkan di Perancis dan dianut di negeri-negeri Eropa Kontinental dan kemudian juga oleh negeri-negeri nasional baru bekas negeri jajahannya. Sementara itu, sistem kedua tersebut berkembang dari tradusu Inggris dan dianut oleh negeri bekas jajahannya.

Terdapat empat karakteristik dalam sistem hukum Barat yang demi kesempurnaan eksistensinya (Wignjosoebroto, 2017) selalu (1) berupa aturan-aturan yang dinyatakan secara eksplisit dalam rumus-rumus pasal/ayat yang tertulis dan tersistematisasi (corpus iuris), (2) mengklaim punya otoritas sebagai satu-satunya hukum yang berlaku pada suatu wilayah teritorial bangsa, (3) dilandasi suatu ajaran atau doktrin bahwa hukum dalam wujudnya yang demikian itu berstatus tertinggi, mengatasi norma-norma sosial lain (ius) yang tidak atau belum dirumuskan dalam bentuknya yang eksplisit, (4) memiliki karakter historisitas, yang berarti bahwa hukum Barat ini selalu berada dalam suatu ruang dan waktu, yang oleh sebab itu selalu mengalami proses perubahan dialektik dialogik secara berterusan, menuju kesempurnannya yang fungsional, dalam upaya menemukan keseimbangan yang tepat antara stabilitas dan fleksibilitas, seolah tak sekali-kali akan bisa bersifat final, (5) dibangun dan dikelola secara rasional dan eksklusif oleh suatu kaum profesional tertentu, dan yang ditunjang oleh hadirnya suatu institusi keilmuan dan pendidikan pada tiingkat universiter.

Belajar dari sejarah Revolusi kemerdekaan Amerika dan revolusi kerakyatan Perancis, yang keduanya terjadi pada belahan akhir abad 18, adalah peristiwa sejarah yang merealisasi ajaran kontrak sosial. Manakala revolusi di Amerika beroleh inspirasi dan ajaran teori kontrak sosial dari John Locke (1632-1704), revolusi yang pecah di Perancis disulut oleh ajaran kontrak sosial Rousseau yang membenarkan pembunuhan atas raja yang tiran. Walaupun realisasi doktrin kontrak sosial itu berlangsung lewat revolusi yang berdarah-darah, lebih-lebih lagi pada revolusi yang terjadi di Perancis, namun demikian doktrin ini sesungguhnya menyiratkan kehendak untuk membangun kehidupan baru yang lebih sejahtera dan berkebebasan bagi rakyat damai. (Hardiman, 2010) 
Doktrin mengajarkan bahwa tidak akan ada hukum yang boleh dianggap sah dan mengikat apabila tidak dibentnuk berbahankan substansi yang berada dan berasal dari sumbernya, ialah rasionalitas manusia, nota bene manusia yang bertindak secara bebas untuk mendudukkan diri sebagai subjek dalam suatu hubungan kontraktual. Hukum hasil bentukan berbahankan substansi yang bisa diterima akal subjek-subjek yang berkontrak inilah karena demi sahnya mengikat itu harus diundangkan yang disebut hukum Undang-Undang, entah undang-undang yang berkualifikasi "dasar" entah yang berkualifikasi "bukan dasar" melainkan yang kemudian diistilahi 'undangundang organik'.

Ajaran Hierarki perundang-undangan, menurut Hans Kelsen (1881-1973) dalam (Wignjosoebroto, 2017).Hukum undang-undang bisa disebut 'Die Stuffenbaulehre'. Menurut ajaran ini, hukum undang-undang bisa disusun dalam jenjang-jenjang anak tangga, dari yang paling tinggi dengan nilainya yang superior ke yang paling bawah dengan nilainya yang inferior. Undang-undang organik yang berstatus lebih inferior tak boleh bertentangan dengan undang-undang dasar yang berstatus superior, karena hukum yang superior akan membinasakan hukum undangundang yang lebih inferior.

Dipandang dan dihargai sebagai hukum yang paling superior, undang-undang dasar selalu perli dikawal agar tidak kehilangan maknanya sebagai hasil perjanjian luhur bangsa sebagai akibat "diobrak-abrik"oleh hukum undang-undang yang merupakan hasil kesepakatan mereka yang berstatus dibawah badan konstituante pembentuk undang-undang dasar.

Batas-batas kewenangan yang dinyatakan secara normatif dalam dan oleh konstitusi itu sesungguhnya tak hanya dimaksudkan untuk menyeimbangkan besaran kekuasaan masing-masing lembaga negara terhadap sesamanya, akan tetapi juga untuk menegaskan batas-batas kewenangan lembaga-lembaga negara tersebut, khususnya di hadapan hak kebebasan warga negara yang asasi.

Proses menegara adalah proses dialektis politis untuk menentukan aturan main hukum yang pasti dan adil untuk bingkai hidup bersama. Maka yang diperlukan adalah konsensus untuk menaruh hormat pada hukum yang adil dan pasti yang ditaati bersama ketika bernegara akhirnya menjadi proses mengatur hubungan dan orientasi kekuasaan atas dasar demokrasi di mana kedaulatan rakyat menjadi penentu pelaksanaan penyelenggaraan negara dalam sistem politik yang membagi kekuasaan dalam 3 bidang mandiri dan saling mengontrol, eksekutif, legislatif, dan yudikatif. Selain itu proses menegara yang dihayati oleh masyarakat majemuk dalam menjadi satu bangsa Indonesia yang beradab itu menaruh kerangka dasar hidup bersamanya dalam paradigma negara hukum dan negara demokrasi. (Sutrisno, 2001)

Paradigma negara hukum mempunyai prinsip - prinsip pokok. Seperti persoalan kontekstual negara hukum muncul dalam sejarah peradaban makala terjadi konflik kepentingan di mana yang "powerfull" (berkuasa) menang terus melawan yang "powerless" (tidak berkuasa). Bentuk-bentuk kuasa itu adalah kemampuan, kekayaan ekonomis, wewenang yang de facto mengendalikan orang lain mulai dari tingkat memaksa kepatuhan sampai pada menyingkirkan sesama yang dipandang musuh entah lewat teror psikologis, fisik sampai pelenyapan berdarah dengan menghabisinya.

Paradigma negara hukum muncul ketika negara sebagai kendaraan politis yang mau mengorganisir dan mengatur hidup bersama lewat kekuatan yang harus ditaati (kekuasaan) akhirnya menjadi mutlak, absolut dan otoriter dalam wajah-wajah monarki mutlak ( di mana kekuasaan memusat ke satu tangan atau satu kelompok 
begitu kuatnya hingga kemerdekaan warga hampir nol); wajah negara kerajaan (di mana sentralisasi kekuasaan menyatu dengan paradigma raja pusat yang harus dipathui, dan meminta ketaatan mutlak dari rakyat). Namun ketika munculnya masyarakat pluralis, yang berdaulat, yang berkeadaan dan berkeadilan dicita-citakan untuk dikonsensuskan sebagai proses politik dalam mencapainya.. Akhirnya wacana pemerdekaan menggumpak dan menyepakati negara hukum dan negara kedaulatan rakyat.

Negara hukum disepakati sebagai aturan main dengan mekanisme untuk mengontrol kekuasaan dan membaginya dalam tiga badan, yaitu legislatif, eksekutif, dan yudikatif. Keprihatinannya jelas, yaitu res publica atau kekuasaan yang dikontrol dan dipertanggung jawabkan secara transparan di hadapan rakyat. Mekanisme yang dipilih adalah sebuah proses politik yang mau menolak mati-matian negara absolutis politik yang mau menolak mati-matian negara absolutis kekuasaan. Tidak hanya itu, para pendiri juga berhasil memilih bentuk negara kedaulatan rakyat atau negara demokratis di mana yang berdaulat adalah rakyat dan bukan elite, penguasa dan kelompoknya, agama tertentu atau kepentingan tertentu. (Wignjosoebroto, 2017)

Paham negara hukum berdasarkan keyakinan bahwa kekuasaan negara harus dijalankan atas dasar hukum yang baik dan adil. Jadi, ada dua unsur dalam paham negara hukum. Pertama, bahwa hubungan antara yang memerintah dan yang diperintah tidak berdasarkan kekuasaan, melainkan berdasarkan pada suatu norma obyektif yang juga mengikat pihak yang memerintah. Dan kedua bahwa norma obyektif itu, hukum memenuhi syarat bukan hanya secara formal, melainkan dapat dipertahankan berhadapan dengan idea hukum. Hukum sendiri harus baik dan adil. Baik karena sesuai dengan apa yang diharapkan masyarakat dari hukum, dan adil karena maksud dasar segenap hukum adalah keadilan.

Ketika terjadi absolutisasi atau pemutlakan kekuasan itulah muncul reaksi dari masyarakat yang dalam pencerahan-pencerahan kesadaran karena mengalami represi, pemasungan dan dikalahkan terus akhirnya sadar diri bahwa hak-hak kemerdekaan warga harus diberi format perlindungan bila dihadapkan dengan kesewenangan kuasa. Format itu adalah hukum. Hukum itu suatu sistem norma-norma yang mengatur kehidupan dalam masyarakat. Bersama dengan norma-norma sopan santun dan moral, norma-norma hukum termasuk dalam kelompok norma umum kelakuan manusia. Di samping norma-norma umum itu terdapat juga berbagai macam norma khusus, seperti misalnya aturan-aturan permainan atau segala macam teknis. Norma-norma yang terakhir disebut khusus, karena hanya berlaku dalam wilayah atau pada waktu yang tertentu saja. (Suseno, 2003). Misalnya peraturan-peraturan dalam perguruan tinggi, peraturan dalam industri maupun peraturan di psat perbelanjaan yang dapat dilupakan ketika kita meninggalkannya diluar waktu kita berada di dalamnya.

Kita dapat bertolak dari pertimbangan bahwa masyarakat tidak menghendaki hukum karena ingin kebebasannya dibatasi dengan segala macam peraturan, melainkan karena tatanan hukum itu menjamin nilai-nilai bersama yang dianggap paling vital. Jadi hukum berkembang dari kesadaran masyarakat bahwa hukum dibutuhkannya demi suatu kehidupan yang dinilai baik dan bermutu. Jadi dasar adanya hukum adalah penilaian masyarakat bahwa hukum itu diperlukan. 


\section{B. Kekuasaan Komunikatif}

Kekuasaan eksekutif menimba kekuatan-kekuatannya tidak dari sumbersumbernya sendiri, melainkan tergantung pada sumber kekuasaan lain yang menghasilkan kekuatan-kekuatan dari dirinya sendiri. Kekuasaan yang dimaksud di sini adalah kekuasaan yang memberikan undang-undang atau seperti disebut dalam ajaran klasik, legislatif.

Satu-satunya sumber kekuasaan tersebut adalah rakyat itu sendiri sebagai pemberi hukum sesungguhnya yang haknya seperti ditegaskan oleh Rousseau yang tidak dapat dialihkan ke suatu instansi lain. Ajaran klasik sepakat bahwa undangundang adalah kristalisasi kehendak rakyat, dan kekuasaan yang memberikan undangundang memiliki hak hidup, hanya jika kekuasaan tersebut selaras dengan kehendak rakyat yang adalah pemilik sesungguhnya dari kekuasaan itu. Ajaran tentang kekuasaan asali rakyat seperti itu dalam masyarakat-masyarakat modern yang kompleks semakin kurang dipahami.

Kekuasaan selalu merupakan potensi kekuasaan, dan bukanlah sesuatu yang tetap, terukur dan pasti seperti daya ataupun kekuatan. Kekuatan adalah apa yang dalam ukuran tertentu dipunyai oleh setiap manusia secara alamiah dan sungguh dapat dianggap sebagai miliknya; namun kekuasaan sesungguhnya tidak dimiliki oleh seorangpun. Kekuasaan terjadi diantara manusia-manusia, jika mereka bertindak bersama-sama, dan dia lenyap, begitu manusia-manusia itu bubar.

Kekuasaan mengacu pada dirinya sendiri, dan hal itu menurut Hannah Arendt, misalnya di dalam perlawanan revolusionner atas penindasan, di dalam tatanan-tatanan politis yang menjamin kebebasan di dalam gerakan ketidakpatuhan warga dan seterusnya. Menurut Habermas memahami kekuasaan komunikatif sebagai kedaulatan sebuah kesatuan sosial yang akan meningkat melalui berbicara dan bertindak satu sama lain. Akan tetapi dia mengambil jarak terhadap konsep Arendt tentang kekuasaan tersebut sekurang-kurangnya dalam hal-hal penting berikut: Pertama, konsep Arendt baginya tampak terlalu ideal dan sulit dicocokkan dengan Realpolitik yang ditandai dengan kekerasan struktural. Menurut lukisan Hannah Arendt kekuasaan terwujud dalam segala kemurniannya dan di dalam sebuah proses formasi aspirasi kolektif yag berlangsung tanpa kendala apapun, seolah-olah kekuasaan dihasilkan sama sekali tanpa sebab diluar dirinya. Di dalam Realpolitik komunikasi kita tidak hanya dibatasi oleh kekerasan struktural yang tak terlihat, sebagaimana jelas dalam ideologi-ideologi, melainkan juga institusi-institusi yang distabilkan melalui kekuasaan politis juga jarang didirikan atas dasar keyakinan bersama. Maka dari itu Habermas menyarankan sebuah versi realistis dari kekuasaan komunikatif: Komunikasi yang menghasilkan kekuasaan itu sedemikian terbatas dan terdistorsi, sehingga kekuasaan baru terbentuk melalui penerimaan faktual atas klaimklaim kesahihan yang terbuka terhadap kritik dan muncul dalam diskursus. Kekuasaan memang terbentuk lewat proses-proses komunikasi, tetapi proses-proses ini merupakan sebuah susunan yang rumit. Bila kekuasaan berakar dalam klaim-klaim kesahihan, menurut Habermas, kekuasaan itu merupakan sebuah upaya rasional dari persetujuan solidaritas. (Hardiman, 2009)

Dengan demikian regenerasi kekuasaan komunikatif terdiri dari persilanganerpsilangan dan jaringan-jaringan yang rumit dari bentuk-bentuk komunikasi dan diskursus-diskursus rasional. Apa yang dimaksud Habermas di sini adalah proses formasi opini dan aspirasi politis atau proses delibrasi kolektif. 
Dalam pandangan Habermas mengenai kekuasaan komunikatif itu tampak jelas motif teori tindakannya. Habermas mencoba memberi pemahaman baru untuk ajaran klasik tentang kekuasaan legislatif dengan menerjemahkannya ke dalam teori tindakan. Kekuasaan yang menjadi dasar bagi semua institusi politis di mengerti oleh Habermas sebagai sesuatu yang mereproduksi dirinya dari tindakan komunikatif. Kekuasaan itu dapat dianggap sebagai sebuah ekstensi dari tindakan komunikatif.

Apabila membahas tentang kekuasaan ppada kuasa sosial, yaitu menggunakan kedua saluran sekaligus. Saluran ini mencakup kekuasaan, sosial, administratif, dan komunikatif. Pada kasus-aksus kuasa yang didasarkan pada status atau posisi, agen bisa memberikan perintah yang secara normatif memang berwenang (maksudnya adalah kewenangan agen itu merupakan bentuk pengakuan praktik sosial), dan didukung oleh ancaman sangsi disiplin bagi yang menentang. Dalam konteks sosial yang diatur secara informal, beragam bentuk kuasa yang tidak menggabungkan kedua elemen ini akan gagal. Kalau perintah itu tidak dikenai sangsi, maka agen akan lemah ketika berhadapan dengan penentang, sehingga tdak bisa menjamin adanya kepatuhan. Kalaupun agen masih memiliki kuasa, maka kuasa itu tidak memiliki dorongan kuat berupa alasan normatif yang mendasar untuk bertindak. Akan tetapi, kalau sebuah perintah tidak memiliki kewenangan normatif maka kuasa agen hanya akan terbatas pada sejauh mana ia (sendiri) bisa menerapkan sangsi, karena dia tidak memiliki landasan untuk menarik orang untuk membantunya dalam menerapkan sangsi. Sekali lagi, kelaupun agen masih memiliki kuasa dalam pengertian tertentu maka itu sepenuhnya tergantung pada kesempatan dan beberapa aspek, variabel situasi dan kondisinya.(Habermas, 2016).

\section{Kekuasaan Administratif}

Pergeseran paradigma ke arah terbentuknya tradisi Hukum Barat, terlihat dari perkembangan sistem hukum yang tak lagi mendasarkan diri pada kebenaran moral lokal melainkan pada preskripsi-preskripsi yang diundangkan dalam kitab-kitab hukum oleh para penguasa sentral pada kekuasaan administratif sebagaimana yang terkisah di muka sesungguhnya lewat berbagai pergeseran paradigma yang telah melahirkan konfigurasi sistem hukum Barat.

Menurut Habermas, hukum menciptakan sebuah mekanisme yang menerjemahkan kekuasaan komunikatif ke dalam kekuasaan administratif. Kekuasan sosial meski memiliki kewenangan normatif, masih mengambil bentuk kehendak individu tertentu. Pekerjaan kuasa administratif, di lain pihak, dipisahkan dari kehendak atau kedaulatan individu dan dilekatkan kepada aturan hukum. Sistem hukum menciptakan aturan dan kewenangan dasar yang menaungi usaha mencapai tujuan kolektif, dan memberi rakyat hak untuk boleh bertindak ketika ketentuanketentuan ini tidak berjalan. Akan tetapi, hukum bukanlah sekedar media untuk menerapkan kekuasaan administratif, namun juga memberikan legitimasi bagi pelaksanaan kkuasa administratif itu. Di bawah aspek legislatifnya hukum bukanlah sekedar media untuk menerapkan kuasa administratif, namun juga memberikan legitimasi bagi pelaksanaan kuasa administratif itu. Di bawah aspek legislatifnya hukum mengklaim merepresentaskan kesepakatan yang bisa diikuti dengan bebas oleh semua orang. Kalau pada awalnya ia lebih cenderung berbentuk konsensus. (Habermas, 2004)

Berbicara mengenai kekuasaan negara berarti terutama berbicara tentang kekuasaan yang melaksanakan undang-undang atau demikian orang menyebutnya 
sejak Locke dan Montesquiue tentang eksekutif. Kekuasaan ini dapat dimengerti sebagai realisasi tujuan-tujuan bersama secara legal. Kekuasaan yang melaksanakan undang-undang ini merepresesentasikan dirinya terutama sebagai administrasi tertinggi atau sebagai pemerintah.

Eksekutif bukan rakyat maupun raja, melainkan dipandang sebagai pusat kekuasaan politis di dalam sebuah negara yang menjadi mediasi antara rakyat dan raja. Konsep kekuasaan administratif yang diajukan Habermas telah meninggalkan gambaran konkret tentang kekuasaan eksekutif seperti yang diberikan oleh Rousseau di atas. Kekuasaan administratif tidak dibayangkan sebagai substansi politis yang terkonsentrasi terutama pada badan-badan politis. Mengkritik asumsi filsafat subjek yang bercokol dalam teori klasik itu, Habermas berpendapat bahwa kekuasaan administratif bukanlah sebuah macro-subjeck yang berkuasa untuk mengendalikan segenap masyarakat. Kekuasaan administratif itu pada analisis terakhir merupakan sebuah tipe kekuasaan yang terdiferensiasi dari wilayah tindakan sosial. Pencapaian tujuan kolektif yang dilakukan oleh kekuasaan administratif dalam kerangka hukum dipikirkan oleh Habermas sebagai bagian penting sebuah sistem sosial. Jadi, kekuasaan administratif ini mengandaikan cara-cara strategis dan profesional untuk merealisasikan tujuan-tujuan kolektif tertentu dengan instrumen-instrumen organisatoris. Kekuasaan jenis ini berakar dalam apa yang disebut Habermas sebagai tindakan strategis. (Hardiman, 2009: 92).

Bagi suatu praktik kekuasaan administratif yang legitim tidaklah memadai, jika orang hanya mengacu pad aundang-undang yang sudah disahkan, melainkan kekuasaan ini harus mengubah keputusan-keputusan kolektif tersebbut dari sudut pandang efisiensi dan presisi. Kekuasaan administratif pada hakikatnya memiliki ciri pragmatis dan terutama memperhatikan sejauh mana undang-undang yang berlaku dapat direalisasika karena kekuasaan administratif bukanlah kewenangan. Max Weber memahami kekuasaan sebagai pengguna sarana untuk memperngaruhi kehendak orang-orang lain dan kekuasaan pada akhirnya dapat dikembalikan pada seorang subjek tunggal yang bertindak atau pada sebuah kelompok yang dikirkan sebagai seorang subjek tunggal. Sementara Habermas mengkaitkannya dengan kekuasaan komunikatif.

\section{Ruang Publik Dalam Politik Masyarakat Demokratis}

Akar utama dalam konsep ruang publik adalah masyarakat warga dan bagaimana masyarakat membentuk dirinya sebagai masyarakat yang berdemokrasi. Untuk mencapai bentuk demokratisasi ini tentunya harus ada politik rakyat sebagai upaya membangun kekuasaan masyarakat bersama. Bingkai demokratisasi sebagai proses penegakkan sistem politik yang selama ini "paling" memberi porsi banyak untuk kedaulatan rakyat dan toleransi pada kemajemukan.

Apa yang inti dari demokrasi? Pertama, ia merupakan sistem politik yang mengantitesis pemusatan kekuasaan di tangan monarki raja atau pemutlakan kekuasaan di tangan segelintir penguasa entah atas namma oligarki atau monarki monopoli yang menguasai penentuan berpolitik di tangan sendiri dengan seluruh kepentingannya sendiri tanpa menghiraukan posisi rakyat. Karena ini merupakan antitesis terhadap politik monopoli pemusatan kekuasaan, maka demokrasi menjadi kritik dan sentralisasi kuasa itu dengan membaginya tiga agar bisa saling mengontrol. Itulah demokrasi "trias politica" dari Montesquiue yang membagi kekuasaan dalam 3 jalur, yaitu yudikatif, legislatif, dan eksekutif dengan kemutlakan syarat independensi 
(kemandirian) untuk bisa saling mengontrol justru untuk mencegah korup dan absolutisnya kekuasaan yang tanpa kontrol itu. Kedua, demokrasi muncul dalam sejarah peradaban menata masyarakat untuk menaruh kedaulatan rakyat sebagai penentu keabsahan sistem politik tata masyarakat atas tata negara. Karena itu yang harus berdaulat adalah rakyat, mereka pulla lah yang mengontrol penentuan sistem hukum atau "tegaknya hukum" sebagai aturan main bagi pelaksanaan kedaulatan dalam pertanggung jawaban hukum. Jadi, bingkai praktek kekuasaan adalah tegaknya hukum. Dan dari sini transparansikan pelaksanaan kedaulatan dalam pertanggung jawaban hukum. Disinilah lalu dikenal demokrasi langsung bila rakyat langsung menentukan suaranya untuk mengekspresikan kedaulatannya. (Sutrisno, 2001)

Sementara politik merupakan proses yang dilakukan rakyat untuk menata hidup bersama dalam sebuah masyarakat. Maka pelaku pokok proses politik adalah rakyat itu sendiri. Rakyat ketika memproses hidup bersama mereka menyepakati berbagai konsensus dan mendialogkan tata laksana aturan main dalam mencapai kesejahteraan bersama dari seluruh warga masyarakat tanpa kecuali.

Apabila demokrasi tidak dimengerti secara minimalis sebagai keikutsertaan dalam pemilihan umum belaka, proses-proses di antara pemilihan umum yang satu dan yang lain haruslah juga dilihat sebagai proses-proses demokratis, karena di antara kedua pemilihan umum itu dapat terjadi berbagai hal yang menghasilkan kesenjangan antara keputusan-keputusan pemilihan umum dan keputusan-keputusan konkret pemerintah. Kekuasaan yang dipraktikkan secara administratif, mengikuti rasionalitasnya sendiri yang dapat menjadi otonom dari sumbernya, yakni rakyat, sehingga rakyat tidak lagi memiliki ruang di antara pemilihan umum yang satu dan yang lain. Tentu saja makna pemilihan umum tidak boleh diperkecil, karena pemilihan umum merupakan locus para warganegara menentukan diri mereka. Akan tetapi pemilihan umum bukanlah satu locus satu-satunya. Jika demokrasi ingin dimengerti secara deliberatif, pemilihan umum dapat dianggap sebagai "hasil pemakaian publik atas hak-hak komunikatif'.(Hardiman, 2009).

Menurut Habermas dalam Hardiman (2009) hak-hak komunikatif para warganegara terlaksana terutama di dalam diskursus-diskursus informal yang dapat dilaksanakan secara inklusif dan dapat mempersoalkan segala tema relevan yang mungkin. Demokratisasi 'ruang-antara' pemilihan-pemilihan umum itu berarti bahwa para warganegara memiliki kemungkinan untuk mengungkapkan pendapat-pendapat mereka sendiri secara publik dan mempersoalkan segala tema yang relevan untuk masyarakat supaya suara-suara yang sensitif terhadap masalah ini dikelola oleh sistem politik yang ada.

Ruang demokratis seperti itu, tempat warganegara dapat menyatakan opiniopini, kepentingan-kepentingan dan kebutuhan-kebutuhan mereka secara diskursif adalah gagasan pokok ruang publik politis. Habermas memahami ruang publik politis itu sebagai prosedur komunikasi. Ruang publik itu memungkinkan para warganegara untuk bebas menyatakan sikap mereka, karena ruang publik itu menciptakan kondisikondisi yang memungkinkan para warganegara untuk bebas menyatakan sikap mereka, karena ruang publik itu menciptakan kondisi-kondisi yang memungkinkan para warganegara untuk menggunakan kekuatan argumen. Ruang publik politis itu sebagai kondisi-kondisi komunikasi bukanlah institusi dan juga bukan organisasi dengan keanggotaan tertentu dan aturan-aturan yang mengikat.(Hardiman, 2009).

Ruang publik dapat dimengerti, di atas segalanya, sebagai ruang masyarakat privat (sphere of private people) yang berkumpul bersama menjadi sebuah publik. 
Mereka mengklaim bahwa ruang publik ini diregulasi dari atas guna melawan otoritas publik. Inilah yang lantas menyeret mereka masuk ke dalam perdebatan seputar kaidah-kaidah umum yang mengatur hubungan-hubungan di dalam ruang pertukaran komoditas dan ruang kerja sosial yang secara mendasar telah terprivatisasi meski secara publik masih relevan. Medium bagi pertikaian politis ini agak istimewa sekaligus tanpa preseden historis sama sekali: pengguna rasio secara publik oleh rakyat. (Habermas, 2009).

Sebelum ruang publik membentuk secara eksplisit fungsi-fungsi politis di dalam medan hubungan antar negara dan masyarakat yang penuh ketegangan, ternyata subjektivitas yang berakar di dalam ruang intim keluarga konjugal teah menciptakan publiknya sendiri. Bahkan sebelum pengendalian terhadap ruang publik oleh otoritas publik ditandingkan, yang akhirnya dimenangkan oleh penalaran kritis manusiamanusia privat mengenai isu-isu politis, sebuah ruang publik dalam bentuknya yang apolitis sudah berkembang di bawahnya lewat perintisan kesusastraan mengenai pengoperasian ruang publik di wilayah politis. Masih menurut pandangan Habermas, bahwa Ruang publik hadir seluas otoritas publik, dan kita dapat melihat istana sebagai bagian darinya. Yang terkandung di wilayah privat adalah 'ruang publik' yang otentik, sebuah ruang yang dibentuk oleh masyarakat privat sendiri. Di wilayah ini, kita dapat memilahkan sekali lagi ruang privat dari ruang publik. Ruang privat mencakup masyarakat sipil dalam pengertian lebih sempit, yakni wilayah pertukaran komoditas dan wilayah kerja sosial dengan berlandaskan ruang dalam keluarga konjugal. (Habermas, 2016).

Konsep ruang publik sangat penting bagi Habermas dalam mengembangkan Teori Kritis karena di situlah medan "pertempuran" berbagai kepentingan masyarakat, ekonomi, dan politik. Oleh sebab itu, prosedur yang mengikat perilaku manusia dalam ruang publik itu harus diperoleh dengan cara-cara yang bersifat komunikatif, yakni pembicaraan bersama yang terbuka dan bebas. (Poespowardojo, Soerjanto, T.M; Seran, 2016).

Apa yang menarik dalam konsep Habermas tentang ruang publik adalah gagasan bahwa ruang publik ini dapat berfungsi secara politis. Masyarakat dapat membayangkan bahwa sebuah negara yang mengaku dirinya demokratis demi kesejahteraan umum atau kepentingan-kepentingan publik campur tangan ke dalam formasi opini di dalam ruang publik, mengontrol keras-keras media massa demi keamanan nasional, menstigma pihak-pihak yang berbeda pendapat sebagai subversif dan menghalang-halangi formasi-formasi spontan kelompok-kelompok dalam masyarakat. Lalu aparat-aparat negara tersebut memberi alasan untuk politik mereka itu bawha negara sudah dilengkapi dengan institusi-institusi resmi yang sah speerti misalnya badan-badan parlementer tempat para warganegara dapat menyalurkan aspirasi dan opini mereka secara benar. Negara macam itu melukiskan dirinya sebagai sebuah sistem kekuasaan administratif yang kuat dan otonom. Apa yang kurang di dalam sebuah negara otoriter bukan hanya sambungan pada sumber legitimasi dan loyalitas, melainkan juga sensibilitas terhadap masalah-masalah politis sesungguhnya yang merugikan tidak hanya solidaritas sosial, melainkan juga mengancam integrasi sistemis negara otoriter itu sendiri.

Lalu bagaimana peran publik itu sendiri? Ruang publik poltiis membangun "struktur intermedier" di antara kedua hal itu. Ia berfungsi sebagai sinyal untuk problem-problem yang harus dikelola oleh negara karena institusi-institusi formal yang berwenang untuk itu tidak dapat menyalurkan ataupun memecahkan masalahmasalah tersebut secara memuaskan. Hal tersebut dapat difungsikan dengan baik 
apabila dapat dipenuhi secara benar jika ruang publik mencerminkan secara transparan masalah-masalah itu. Jadi, persyaratan untuk sebuah ruang publik yang berfungsi secara politis adalah ciri otonomnya dari kekuasaan administratif negara dan dari kepentingan-kepentingan -kepentingan pasar kapitalis. (Hardiman, 2010)

Jaminan konstitusional untuk ruang publik atau masyarakat warga yang otonom tersebut sudah melekat pada konstitusi demokratis negara hukum. Hak-hak dasar ini menstrukturisasi ruang publik dalam kaitanya dengan ruang tindakannya, dengan keamanan infrastruktur-infrastruktur medianya, dengan hubungannya dengan sistem politik dan dengan pluralismenya.(Hardiman, 2009).

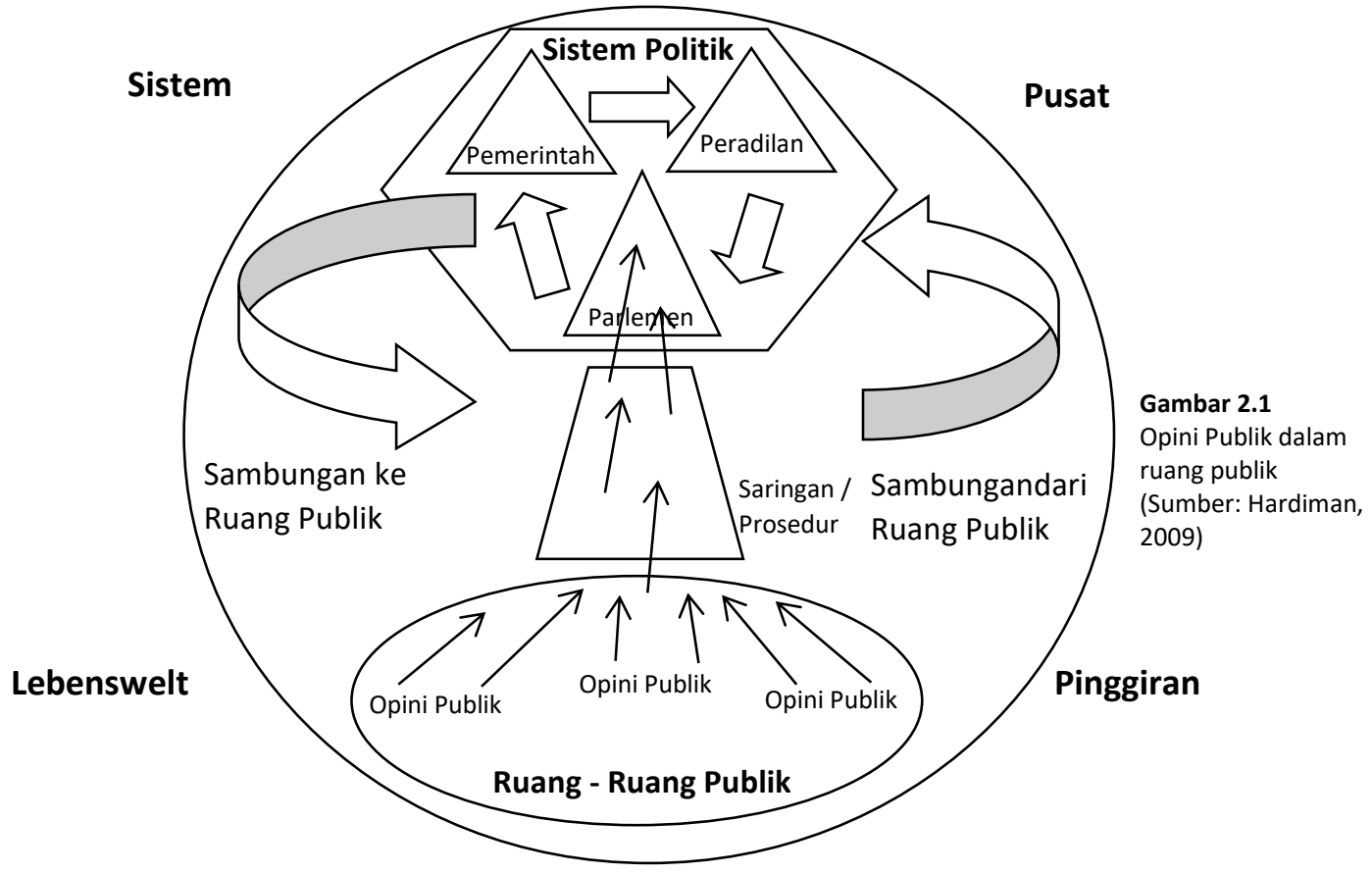

Ruang publik mengandung potensi kekuasaan yang tidak mengecualikan kekuasaan sosial, yakni pemaksaan kehendak sendiri di hadapan orang lain. Dalam pandangan Habermas (Hardiman, 2009), sebuah politik boleh menyatakan dirinya sebagai deliberatif hanya jika tersedia sebuah prosedur diskursif yang mentransformasikan pengaruh-pengaruh ruang publik termasuk kekuasaan sosial menjadi kekuasaan poltiis yang dihasilkan secara komunikatif.

Habermas memodelkan arus-arus komunikasi yang mengalir dari ruang publik menuju sebuah formasi aspirasi yang diatur sesuai prosedur dalam apa yang disebut "model bendungan". Menurut model ini negara hukum demokratis terdiri atas pusat dan pinggiran. Proses penemuan keputusan dapat dilukiskan sebagai arus komunikasi dari pinggiran menuju pusat formasi aspirasi secara diskursif. Diskursifitas terjadi di kedua sisi itu, maka model ini melihat demokrasi sebagai "proses dua jalur". Pinggiran yakni ruang publik politis pada umumnya bertanggung jawab untuk menemukan, menafsirkan dan mengartikulasikan masalah-masalah sosial-politis sebagai 'masukan' untuk pusat. Pusat ini adalah sistem politik yang terdiri atas pemerintah, peradilan, parlemen dan partai-partai politik. (Hardiman, 2010)

Hukum tidak hanya berfungsi pada ranah teori tindakan sebagai poros antara Lebenswelt (Dunia kehidupan) dan sistem, melainkan juga pada ranah teori legitimasi 
sebagai medium transformasi kekuasaan komunikatif menjadi kekuasaan administratif. Para ranag teori legitimasi ini hukum memainkan tiga peran sekaligus: sebagai hasil deliberasi, sebagai alasan untuk melaksanakan program-program kolektif dan sebagai pemecahan konflik.

Menurut Habermas kekuasaan legislatif, eksekuif dan yudikatif sebenarnya merupakan diferensiasi-diferensiasi bentuk-bentuk komunikasi yang mmemiliki titik orientasi mereka dalam hukum. Jika kekuasaan politis ditafsirkan sebagai konsep diskursus, dan karenanya juga terkait erat dengan klaim-klaim kesahihan, macammacam kekuasaan negara diatas dapat dimengerti sebagai potensi-potensi dari alasanalasan. (Hardiman, 2009)

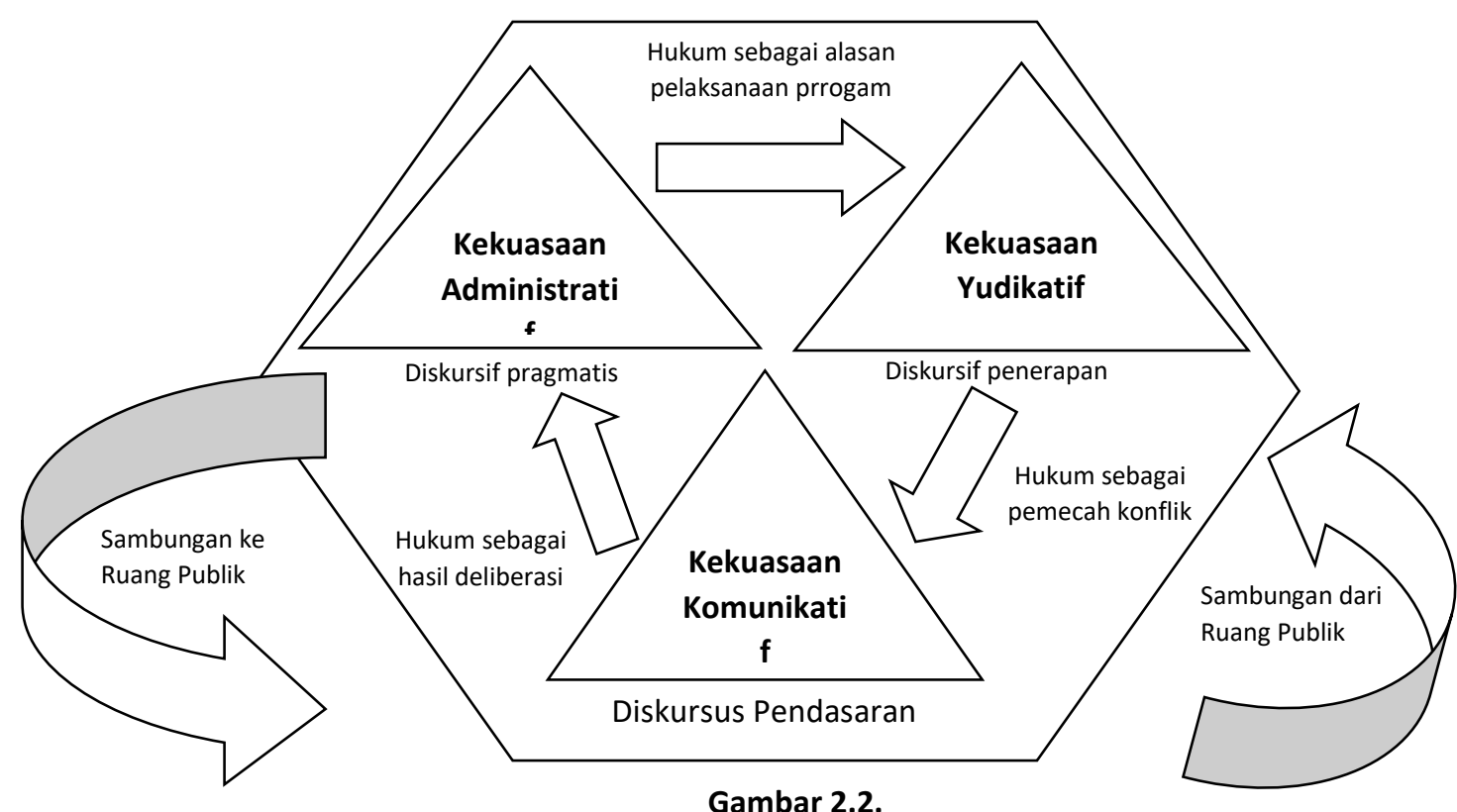

Pembagian Kekuasaan sebagai Sirkulasi Komunikasi Diskursif dalam Sistem politi dan

U., l.um ICumhar. Uardiman Jnnol 
Legislasi dan yurisdiksi bergerak dalam horison pemberian alasan-alasan normatif: sementara legislasi melegitimasikan alasan-alasan normatif tersebut sebagai hukum melalui diskursus-diskursus pendasaran, yurisdiksi merupakan alasan-alasan normatif itu dalam kasus-kasus konkret praktis melalui diskursus-diskursus penerapan. Kemudian administrasi memandang hukum sebagai program yang pelaksanaannya ditentukan lewat diskursus-diskursus pragmatis. Karena terbatas pada pelaksanaan kekuasaan komunikatif, kekuasaan administratif tidak boleh mengintervensi proses legislasi dan yurisdiksi.

\section{KESIMPULAN}

Berdasarkan kajian pembahasan yang telah diulas sebelumnya dalam kaitannya ranah hukum dengan masyarakat dan juga bagaimana konteks hukum di dalam ruang publik masyarakat demokrasi, dapat disimpulkan dalam beberapa hal sebagai berikut:

1. Tonggak utama di dalam konsep hukum dalam masyarakat dan konsep ruang publik adalah inti dari demokrasi yaitu penentu kedaulatan rakyat dan rakyat mengekspresikan dan mencapai kepentingannya untuk menikmati kesejahteraan lewat sistem bernegara, di sana bingkai praktek kuasa adalah transparansi kepastian hukum serta kontrol pelaksanaan kuasa itu apakah ia memberikan kesejahteraan, keadilan dan menjamin hak berdaulat rakyat atau tidak. Absahnya kekuasaan dijalan entah lewat perwakilan atau "trias politica" masuk dalam apa yang disebut sebagai legitimasi. Artinya absahnya demokrasi diuji dan diukur dari kesejahteraan yang dirasakan rakyat serta keadilan yang dirasakan sehari-hari dan jaminan konflik kepentingan antara rakyat dan pemerintah diselesaikan dalam peradilan hukum yang pasti dan adil. Selain itu adanya kekuasaan yang berifat administratif dan komunikatif yang dimana membentuk suatu aturan dan normanorma yang menjalankan masyarakat demokrasi serta bersifat politis dalam membentuk suatu hegemoni. Sementara itu dalam konsepsi ruang publik adalah wadah demokrasi yang dibentuk dengan didasarkan pada komunikasi yang di jalin dalam konsep-konsep klaim validitas publik yang mengutamakan keterbukaan, ketepatan dan kejujuran. Tindakan komunikatif yang membentuk opini publik dalam merancang suatu regulasi yang ditegakkan dan diabsahkan melalui kekuasaan eksekutif, yudikatif dan legislatif.

2. Esensi Hukum dan Ruang Publik pada dasarnya adalah dualitas di dalam strukturnya. Pada Ruag Publik menghendaki beberapa syarat sebagai berikut: Pertama, setiap partisipan (publik/masyarakat) harus diberikan ruang untuk berpartisipasi aktif dalam diskursus serta bebas mengajukan berbagai keberatan (kritik) atas sudut pandang peserta atau partisipan lain. Kedua, dialog yang berjalan mesti bebas dari paksaan, dominasi dan permainan kuasa. Ketiga, partisipan dapat memahami perbedaan kriteria validitas klaim-klaim teoritis, moral-praktis dan estetis yang muncul dalam dialog lantas menyelesaikan dialog dan perbedaan melalui argumen. Keempat adanya persetujuan atau konsensus rasional terbuka terhadap perubahan dan pertimbangan lebih lanjut. Sementara hukum mengkomunikasi pasal-pasal atau ayat yang bersifat memaksakan kepada publik agar mengikuti aturan. Sehingga keutamaan fungsi penyatuan hukum dan ruang publik sulit diterapkan secara ideal. Namun di satu sisi, hubungan yang melekat diantara keduanya (Hukum dan Ruanng Publik) adalah publik/masyarakat melalui suatu ruang demokrasi dan politisnya bisa menghendaki pemegang amanat kekuasaan adminisratif negara untuk 
membangun suatu aturan yang mengatur dan membina masyarakat itu sendiri. Selain itu, bisa menjadikan hukum sebagai tata aturan masyarakat di dalam ruanng publik. Sehingga kebebasan masyarakat tidak bersifat absolut, sementara bersifat absolut demi kelancaran hidup bermasyarakat dan mencegah adanya konflik kepentingan dan politis yang mengarah pada pelanggaran-pelanggaran tertentu.

3. Adanya keberadaan hukum dinilai penting dalam kehidupan masyarakat demokrasi didalam lingkup ruang publik adalah kembali pada fungsi hukum yang utama adalah memanusiakan penggunaan kekuasaan. Dengan adanya hukum konflik kepentingan antar anggota masyarakat tidak dipecahkan menurut tolok ukur kuat lemah, melainkan menurut kriteria yang ditetapkan secara obyektif dan yang sama-sama berlaku bagi semua, baik bagi yang lemah, maupun bagi yang kuat. Selain itu pentingnya hukum maupun aturan di dalam ruang publik, mencakup nilai-nilai dasar hukum yaitu Kesamaan. Hukum berlaku kesamaan terutama kedudukan dihadapan hukum. Hukum menjamin suatu kedudukan dasar yang sama bagi semua anggota masyarakat dalam merealisasikan harapan hidup mereka. Pada kesamaan juga berlaku dalam keadilan, adalah keadaan antar manusia di mana semua diperlakukan dengan sama, artinya sesuai dengan hak dan kewajiban masing-masing. Kemudian nilai dasar berikutnya adalah Kebebasan, bahwa hukum mencegah si kuat dari mencampuri dan mendominasi kehidupan kita, langsung menunjukkan bahwa hukum secara hakiki harus melindungi kebebasan mereka yang ada dibawahnya. Fungsi hukum sebagai penjamin kebebasan. Pembatasan kebebasan melalui hukum secara hakiki terbatas sendiri, sedangkan perbudakan si lemah dibawah si kuat secara hakiki tak terbatas. Maka hukum tetap menjamn kebebasan hakiki manusia. Hukum adalah tatanan normatif yang tidak berdasarkan paksaan semata-mata, melainkan berdasarkan pengakuan masyarakat sendiri. Maka pembatasan-pembatasan yang kita alami dengan adanya hukum, meskipun kadang-kadang kita rasakan berat karena bertentangan dengan suatu keinginan kita, pada dasarnya kita terima dann kita akui. Selain itu hukum juga secara hakiki harus melindungi kebebasan para anggota masyarakat. Kemudian nilai dasar terakhir adalah Solidaritas. Nilai ini secara hakiki harus dilindungi hukum tentunya kebersamaan. Hukum adalah institusionalisasi merupakan makhluk sosial yang secara hakiki harus hidup bersama, ia memerlukan suatu tatanan normatif bagi kelakukannya. Pembatasan diri umat manusia melalui upaya hukum merupakan pengakuan institusional terhadap solidaritas antarmanusia.

\section{SARAN}

Implementasi hukum untuk penerbitan aturan masyarakat harus dijalankan atas dasar moral dan tanggung jawab serta mengedepankan hak-hak masyarakat dalam berinteraksi dan egaliter di ruang publik. Dalam ranag ruang public perlu melihat kembai tentang dasar persamaan hak masyarakat sebagai warga Negara ranah kebebasan berekspresi di ruang public dan tidak menguasai masyarakat dengan dominasi kekuasaan serta legitimasi yang berlebihan. Ruang publik tidak hanya didefinisikan sebagai ruang terbuka seperti ruang fisik, namun perlu dipahami bahwa ruang publik dapat berupa ruang kebebasan masyarakat berada dibawah hukum. Aturan perundang-undangan harus tetap menjaga masyarakat untuk tidak berada diatas hukum (above the law) seperti menghalalkan politik uang atau politik kekuasaan serta dinasti kekuasaan yang sudah turun temurun, melainkan secara terbuka 
memperlakukan semua warga Negara secara hukum dan berada dibawah tekanan hukum dalam aturan-aturan yang berlaku.

Hendaknya pemerintah tidak menyalahi kontrak kesepakatan sosial. Hukum dibuat harus "tajam keatas, tumpul kebawah" bukan untuk sebaliknya. Namun pada fenomena yang berkembang akhir-akhir ini dan terpublikasikan di media massa masyarakat kerap direnggut hak-hak hukumnya hanya kalah dengan kepentingan borjuasi atau kepentingan kapitalis dengan harapan tidak meninggikan hak-hak borjuasi diatas dan merendahkan masyarakat kecil dibawah hukum. Ranah ruang publik perlu menegakkan nilai-nilai egaliter bahwa masyarakat dalam tindakan komunikatif serta kebiasaan yang dijalankan sehari-hari tidak selalu berada dibawah tekanan kekuasaan hukum kecuali bila masyarakat melanggar aturan perundangaundangan yang dimana pemerintah juga tetap konsisten menjalankan kontrak sosial sesuai dengan hukum positif yang berlaku.

Ruang Publik pada dasarnya menekankan hak berbicara sebagai ruang komunikasi yang egaliter. Hal ini diatur dalam Pasal 28 Undang-Undang Dasar 1945 ("UUD 1945") yang berbunyi: "Kemerdekaan berserikat dan berkumpul, mengeluarkan pikiran dengan lisan dan tulisan dan sebagainya ditetapkan dengan Undang-undang". Meskipun secara lisan mudah untuk diucapka dan secara administrative dibuat, namun pada penerapannya kerapkali tidak berjalan demikian karena ruang public masih banyak yang menganggapnya sebagai ruang pembelotan yang dilakukan oleh rakyat. Sehingga kerapkali bagi para kepentingan politik haluan kanan, pergerakan didalam ruang public kerap dianggap mengancam dan perlu menutup akses ruang kebebasan berpendapat dengan ruang otorisasi penguasa. Hal ini tentunya juga melanggar atas hak-hak masyarakat mengatasnamakan Undang-Undang seperti halnya kasus- kasus berkembang di sarana Informasi Teknologi Elektronik (ITE) yang secara mudah menjerumuskan seseorang hanya karena tidak terima dengan kebebasan berpendapat.

\section{UCAPAN TERIMA KASIH}

Penulis mengucapkan terima kasih kepada seluruh civitas akademika Universitas Satya Negara Indonesia dan juga Lembaga Penelitian dan Pengabdian Kepada MAsyarakat yang telah menyediakan sarana pengerjaan tulisan jurnal ini dan juga secara administrative. Selain itu juga mengucapkan banyak terima kasih kepada seluruh Dosen Tetap Program Studi Hukum yang telah banyak memberikan saran dan juga dukungan literature dalam pengerjaan artikel literature review ini.

\section{DAFTAR PUSTAKA}

Habermas, J. (2004). Krisis Legitimasi (J. Habermas (Ed.); 1st ed.). Qalam.

Habermas, J. (2009). Teori Tindakan Komunikatif: Kritik atas Rasio Fungsionalis. Buku 2 (I. R. Muzir (Ed.); 1st ed.). Kreasi Wacana.

Habermas, J. (2016). Ruang Publik (I. Ny. R. Muzir (Ed.); 1st ed.). Kreasi Wacana.

Hardiman, F. B. (2009). Demokrasi Deliberatif. Menimbang "Negara Hukum” dan "Ruang Publik" dalam Teori Diskursus Jurgen Habermas. (F. B. Hardiman 
(Ed.); 1st ed.). Pustaka Filsafat.

Hardiman, F. B. (Ed.). (2010). Ruang Publik. Melacak "Partisipasi Demokratis" dari Polis sampai Cyberspace (1st ed.). Pustaka Filsafat.

Poespowardojo, Soerjanto, T.M; Seran, A. (2016). Diskursus Teori - Teori Kritis. Kritik atas kapitalisme Klasik, Modern, dan Kontemporer (A. Poespowardojo, Soerjanto, T.M; Seran (Ed.); 1st ed.). Kompas.

Suseno, F. M. (2003). Etika Politik. Prinsip-prinsip Moral Dasar Kenegaraan Modern (F. M. Suseno (Ed.); 1st ed.). Gramedia Pustaka Utama.

Sutrisno, M. (2001). Humanisme, Krisis, Humanisasi (M. Sutrisno (Ed.); 1st ed.). Penerbit Obor.

Wignjosoebroto, S. (2002). Hukum. Paradigma, Metode dan Dinamika Masalahnya (E. Kasim, Ifdhal; Yudho, Winarno; Moniaga, Sandra; Fauzi, Noer; Simarmata, Ricardo; Sius RL (Ed.); 1st ed.). Penerbit ELSAM.

Wignjosoebroto, S. (2013a). Hukum dalam Masyarakat (S. Wignjosoebroto (Ed.); 2nd ed.). Graha Ilmu.

Wignjosoebroto, S. (2013b). Hukum Konsep dan Metode (S. Wignjosoebroto (Ed.); 1st ed.). Setara Press.

Wignjosoebroto, S. (2017). Pergeseran Paradigma dalam Kajian-Kajian Sosial dan Hukum (S. Wignjosoebroto (Ed.); 1st ed.). Graha Ilmu. 